\title{
BRAND IMAGE AND PURCHASE INTIENTION: A CASE OF REFRIGERATOR MARKET IN SRI LANKA
}

\author{
By \\ INDIKA NALIN JAYAWICKRAMA
}

GS/MC/2395/2004

A thesis submitted to the University of Sri Jayewardenepura in partial fulfillment of the requirements for the Degree of Master of Science in Management (Marketing) on June 2013. 
The work described in this thesis was carried out by me under the supervision of Mrs. D.S.R. Samarasinghe, Senior Lecturer Department of Marketing in University of Sri Jayewardenepura, and a report on this has not been submitted in whole or in part to any university or any other institution for another Degree/Diploma.

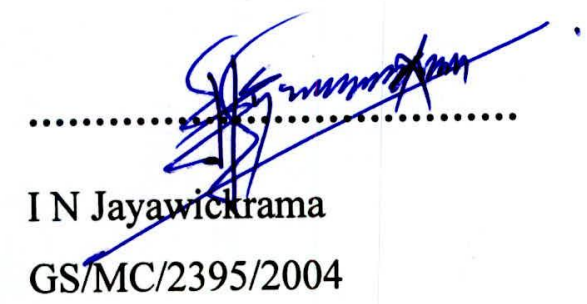


I certified that the above statement made by the candidate is true and that this thesis is suitable for submission to the University for the purpose of evaluation.

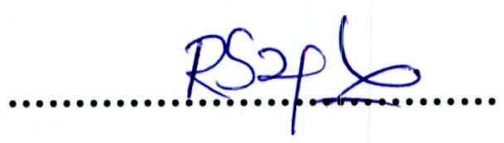

Mrs. D.S.R. Samarasinghe

Department of Marketing

University of Sri Jayewardenepura 


\section{Acknowledgment}

First of all, I would like to thank Mrs. D.S.R. Samarasinghe, Senior Lecturer Department of Marketing in University of Sri Jayewardenepura, for the supervision and guidance extended to me all throughout. I acknowledge with grate gratitude, the encouragement given to me by Dr. B.N.F Warnakulasooriya, Senior Lecture, Department of Marketing, University of Sri Jayewardenepura. Also, I would like to thank Dr. P J Kumarasinghe Course Coordinator of Msc (Management) Degree Programme, Faculty of Graduate Studies, University of Sri Jayewardenepura for helping with official matters.

I specially thank my wife Anu, sons, Abi and Pumilaka and daughter Upethma for their support, encouragement and endurance given throughout this effort, even by postponing their personnel needs, to see me succeed in this effort.

Finally, I would like to thank all those numerous people, whose names are not mentioned, but whose support is greatly appreciated. 


\begin{abstract}
The development of the home appliances market in Sri Lanka was initiated with the liberalization of the economy. Ever since market has shown tremendous growth and that has mainly identified the life style of modern consumers. Nevertheless, customers are in the refrigerator market tend to value maximizes, within the bound of search costs and limited knowledge, mobility and income. Therefore customers estimate which offer will deliver the most perceived value and act on it. Whether or not the offer lives up to expectation affects, customer satisfaction and the probability that he or she will purchase a refrigerator again.
\end{abstract}

This study was conducted as an exploratory type of research to find out through a problem situated to provide insight of purchase intention of refrigerator market in Sri Lanka as considering the key association and differentiation component structured around three perspectives on the brand, the brand as product (value) the brand as person (brand personality), the brand as origination (organizational association) and differentiation are straightly related to brand image. Furthermore the research attempts to identify the influence of brand image to purchase intention in the refrigerator market for making objectives for brand image and purchase intention. Also variables and hypothesis were developed by using the key brand image component of association and differentiation.

In conclusion, a multiple regression was conducted to ascertain the correlation of brand image and purchase intention also, ANOVA tested of the model and was significant and it had adjusted R2 of $63.89 \%$ this means the regression model is meaningful. Furthermore slope coefficients are also, significant at $1 \%$ level proving the positive relationship between brand image and purchase intention. 


\section{List of tables}

Acknowledgement i

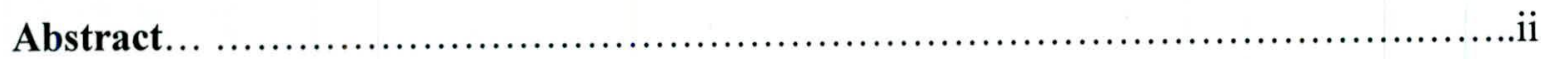

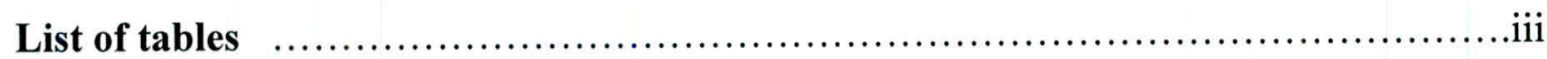

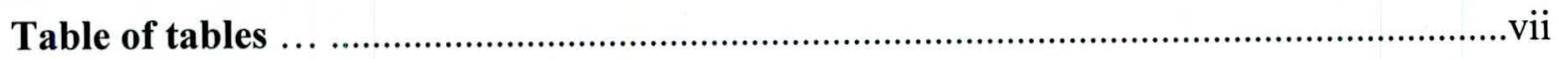

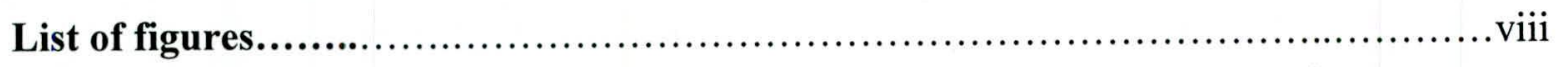

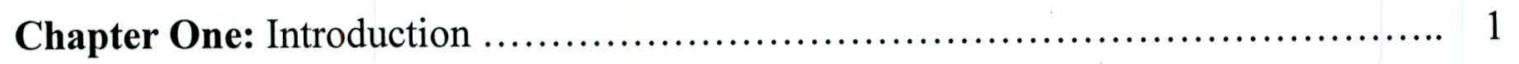

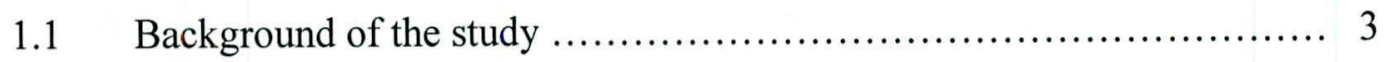

1.2 Background of the refrigerator market.......................... 3

1.2.1 Introduction to Singer ................................. 3

1.2.2 Introduction to Abans .................................. 5

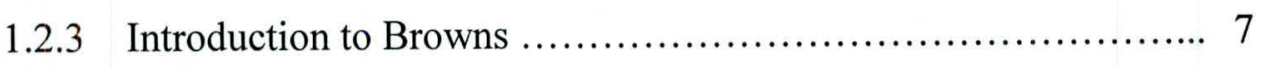

1.2.4 Introduction to Singhagiri............................... 8

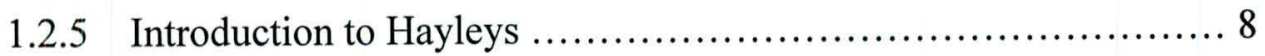

1.2.6 Introduction to Uniwalkers $\ldots \ldots \ldots \ldots \ldots \ldots \ldots \ldots \ldots \ldots \ldots \ldots \ldots$

1.2.7 Introduction to Hanters . ................................ 9

$1.3 \quad$ Research problem and problem statement......................... 9

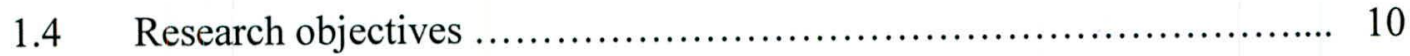

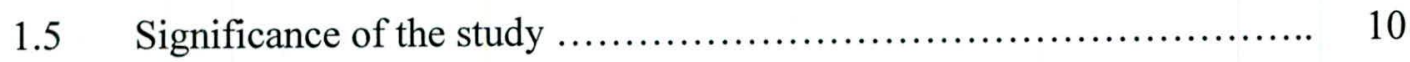

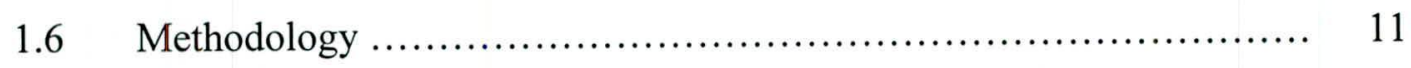

1.6.1 Research design ........................................ 11

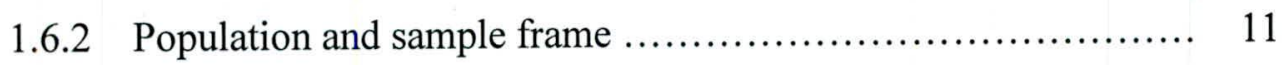

1.6.3 Sample technique ............................................. 11

1.6.4 Method of data collection................................ 11 


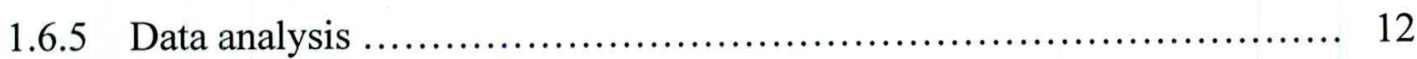

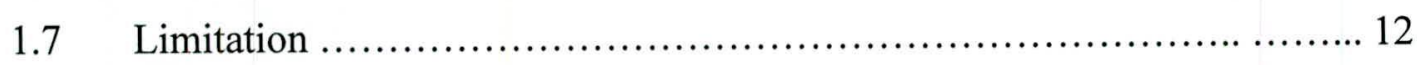

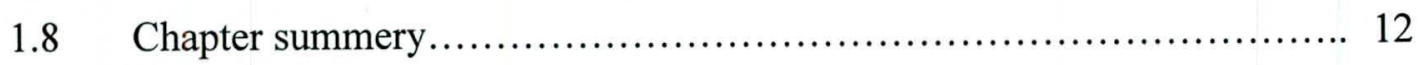

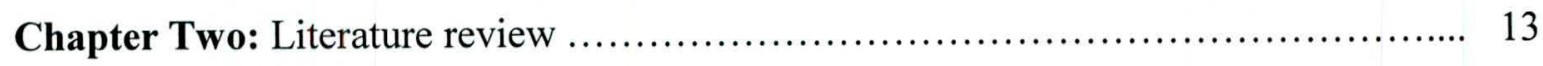

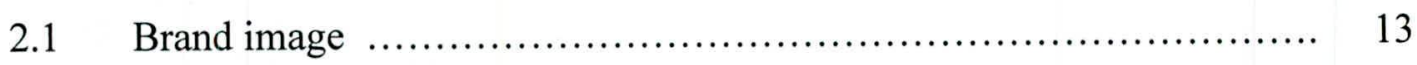

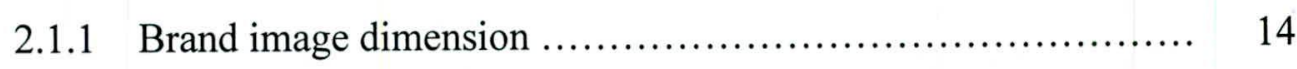

2.1.1.1 Brand image association $\ldots \ldots \ldots \ldots \ldots \ldots \ldots \ldots \ldots \ldots \ldots, 14$

2.1.1.2 Association and differentiation ................... 15

2.1.1.2.1 Brand value ........................... 15

2.1.1.2.2 Brand personality ...................... 15

2.1.1.2.3 Organization association ................. 16

2.1.1.2.4 Differentiation ........................... 16

2.1.1.3 Brand image perception ......................... 17

2.1.1.4 Brand image belief.............................. 18

2.1.1.4.1 Positive brand belief ..................... 18

2.1.1.4.2 Negative brand belief ................... 19

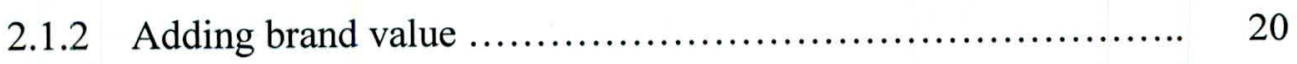

2.1.3 Brand image relevance ................................. 21

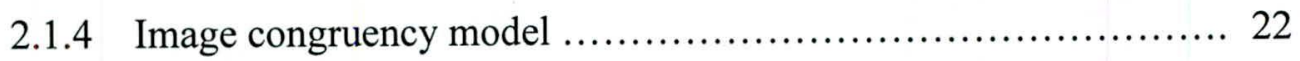

2.1.5 Image congruency hypothesis........................... 23

2.1.5.1 Consumers' self image and favorable evaluation........... 24

2.1.6 Physical attributes and brand image ......................... 25

2.1.7 Brand origin and significant effect on brand image perception ... 25

2.1.8 Negative effect of brand image ......................... 27

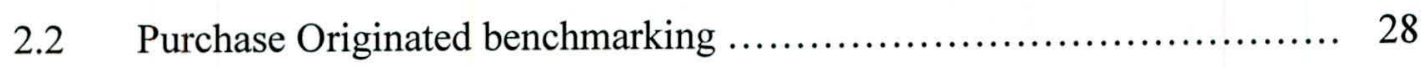


2.2.1 Consumers' brand perceptions and purchase intentions.......... 29

2.2.2 Purchase situation and brands............................ 29

2.2.3 The value of the brand depend on the customers .............. 30

2.2.4 The buying decision process and brand image ............... 30

2.3 Summary of hypothesis development and conceptual model ................31

2.3.1 Theoretical model....................................... 31

2.3.2 Conceptual model............................................. 34

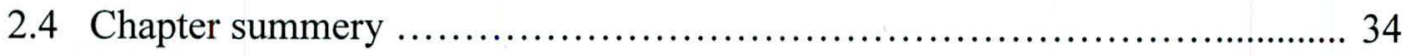

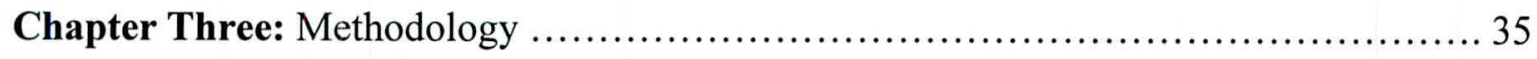

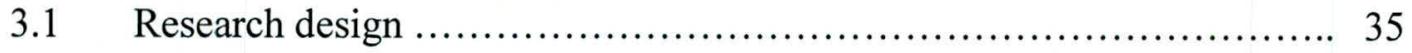

3.2 Operatianalization of the brand image and purchase intention ..............35

3.3 Population and sample frame................................ 37

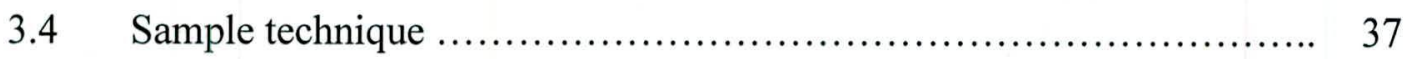

3.5 Method of data collection ........................................ 38

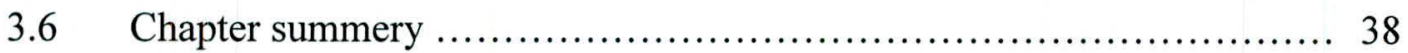

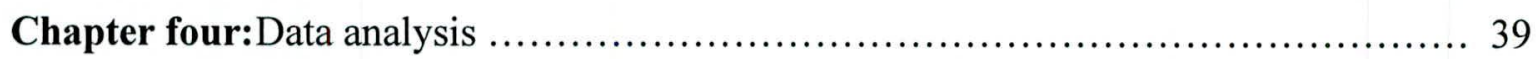

4.1 Market survey ............................................... 39

4.2 Market Survey from primary data ................................... 39

4.3 The finding of the correlation analysis ............................ 41

4.4 Relationship between purchase intention and brand image............. 42

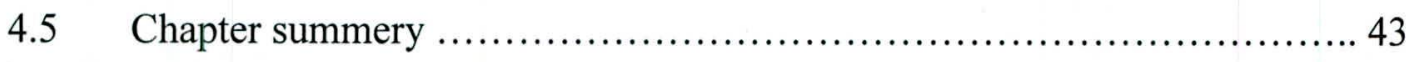

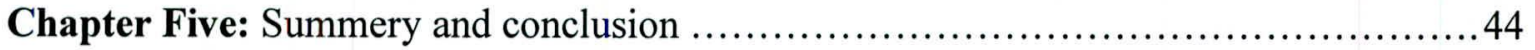

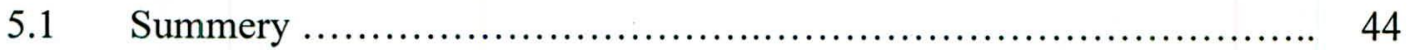

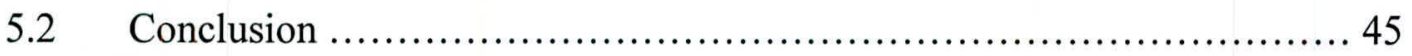

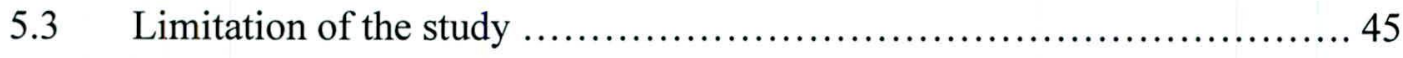

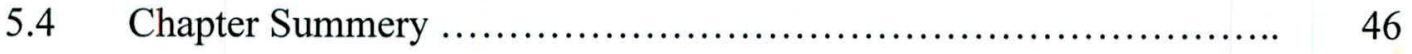


Appendices:

Appendix 01: The questionnaire given to refrigerator customers..........

References

51 


\section{Table of Tables}

Table 1.2.1 Type of refrigerators and brands of Singer Sri Lanka Ltd .............. 04

1.2.2 Type of refrigerators and brands of Abans Group Ltd ................ 06

1.2.3 Type of refrigerators and brands of Browns Company Ltd .............. 07

1.2.4 Type of refrigerators and brand of Singhagiri Ltd ...................... 08

Table 4.3 Mean value of customers purchase intention .......................... 40

4.4 The percentage of customers' purchase intention........................ 40

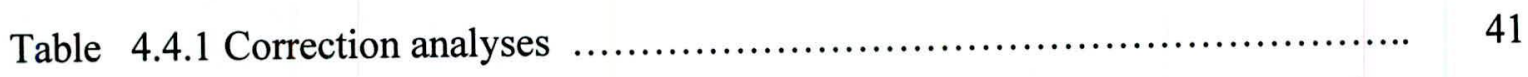

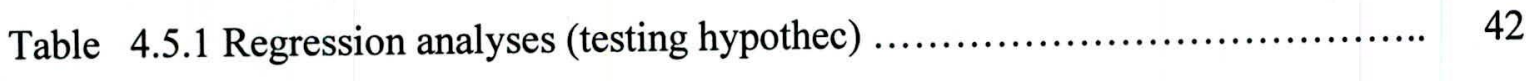




\section{Table of Figures}

Figure 2.1.4 Multiple component perspective of self image.......................... 22

Figure 2.1.5 Consumer self image and favorable evaluation of brand image............. 24 


\section{Chapter One}

\section{Introduction}

The objectives of this chapter are to provide an orientation for the readers in order to understand the detailed information contained in the later chapters. It includes background, refrigerator market leaders in Sri Lanka, research problem, problem statement, research objectives, methodology, significance of the study, method of study and limitation

\subsection{Background of the study}

A refrigerator was a luxurious product in 1970 and later it was changed and become a common product and an essential equipment following the liberalization of the economy and the congested lifestyle of the people. Presently the refrigerator market shows a remarkable improvement in the home appliances market in Sri Lanka. Consumers evaluate the product, differently depending on how it is branded. Consumers learn about brands through marketing programmes and past experience of the product. Found out which brand satisfied their needs and which did not.

Customers spend considerable amount of money to purchase a refrigerator bound by search cost, limited knowledge, mobility and income and also, they wish to maximize the value for money. Therefore customers estimate which offer delivers the most perceived value and act on it, whether the offer lives up to expectation, affects of customers' satisfaction and the probability of repurchasing. They have the tools of verity companies' claims and seek out superior alternatives. Also, consumers in the refrigerator market are more educated in Sri Lanka and informed than ever.

This study was selected the most commonly used and prominent product of refrigerator and its market in Sri Lanka and, based on Arker (1996) stated the key association and differentiation components of brand equity usually involves image dimensions that are unique to a product class or to a brand. The challenge then, is to generate general measures that will work across the refrigerator classes. The measurement of association and differentiation of a brand image can be structured around three perspectives, the brand as a product (value), the brand as a person (brand personality) and the brand as an organization (organization association). The value proposition which usually involves a number of benefits, are basic to brands in most product classes. If the brand does not generate value, it will usually be vulnerable to competitors. 
Brand personality is based on the brand as personal perspective, for some brands personality can provide a link to the brands emotional and self expressive benefits as well as a basis for customer/ brand relationships and differentiation. Another dimension of brand association is the brand organization perspective, which considers the organization people, values and programs. The differentiation is a bottom line characteristic of a brand. If a brand is not perceived as being different, then it will have a difficult time supporting a price premium or maintaining a price that will support an attractive margin. However this research is carried out in the refrigerator market and is presently operating with a limited number of sellers and they have influenced the whole market, also many companies have introduced key associations and differentiation components that involves image dimensions which are unique to a refrigerator or a brand.

Ataman and Ulengin (2003) emphasized on the study of marketing and consumer behavior. The factors that affect the purchase and use of goods and services such as availability, advertising, image and consumer characteristics in their study of marketing and consumer behavior. In the situation where consumers have a choice in how they behave and show the behavior is governed by many factors. Bromley (1993) revealed these factors include their needs, desires, attitudes, expectations and understanding of what is the available, their financial resources and their decision processes.

The relationship between the customers and the brands, the consumers' intention of that brand is the key to brand acceptance. Hankinson and Cowking (1993) noted the strength of the relationship between the consumer and the brand will reflect the corelation the consumers' own physical and psychological needs and the brand's functional attribute and symbolic values, as perceived by the consumers. According to Ataman and Ulengin (2003) brand name image usually includes the product's name, it's main physical features and appearance (including the packaging and logo), is the key to answer the question of how the consumer chooses among alternative brands behave after information gathering process of buyer behavior.

In sum, focusing to the research and concentrating all the explanations of literature revealed, psychological attributes, different marketing components and behavior of refrigerator customers, this research has significantly demonstrated the relationship of brand image and purchase intention of refrigerator market in Sri Lanka. 


\subsection{Background of the refrigerator market leaders}

During the research following major players were identified and who dominate the refrigerator market in Sri Lanka.

\subsubsection{Introduction to Singer}

According to the research data, Singer Sri Lanka is a quoted public company in Sri Lanka and dates back to 1877. Presently it is marketing as a multinational company in the world. Singer is successfully operating in Sri Lanka refrigerator market. According to Singer Sri Lanka annual report (2007) Singer sales of refrigerators fell by $5.4 \%$ year-by-year, an effect attributable to the white goods market. Adjusting to market conditions, Singer has developed new models to achieve margin growth in refrigerators.

According to Singer Sri Lanka annual report (2006) Singer has won Niesen award as the most popular brand. Furthermore the sales have grown up by $19 \%$ as Singer has brought new ground, introducing the concept of the Mega store - a one-stop, all-under-one-roof store, in luxurious surroundings which includes restaurants and kiddies play area for ease and convenience of the customer.

Singer is one of the leading company involved in refrigerator market manufacturing refrigerators as the one of the leading home appliances product and the product rage is consisted sewing machines, televisions, refrigerator, washing machines, two wheeled tractors and domestic/agro water pumps and sprayers. According data the marketing operations are mainly focused in island wide and retailing network is a 153 retail outlets, 118 Singer exclusive dealers and close to 300 independent dealers.

The managing process is controlled by branch manager and the rest of the staff, are employees as working staff, he/she takes the total control of the operation. Manager is given a percentage from the profit as an incentive. Hence, type of sale, collection, whatever the scheme carried out by the outlet is sole discretion of the manager. Mega showroom is positioned by Singer as multi brand total household solutions outlets. Singer sales different type of refrigerator under different brands. 
Table 1.2.1: Type of refrigerators and brands of Singer Sri Lanka Ltd

\begin{tabular}{|l|l|}
\hline Brand & Description of refrigerator \\
\hline Singer & $150 \mathrm{~L}$ Single Door \\
\hline Singer & $360 \mathrm{Ltr}$ Single Door \\
\hline Singer & 47 L Single Door \\
\hline Singer & 85 CB FT. DBL Door NST, TECH \\
\hline Whirlpool & 220 L Deodorizer \\
\hline Whirlpool & 220 L Twistwer \\
\hline Whirlpool & 240 L 2 Shelves \\
\hline Whirlpool & 250 L 6 ${ }^{\text {th }}$ Sense, Flexi Chill \\
\hline Whirlpool & 400 L ICE Twister \\
\hline Sisil & 240 L Double door, multi air \\
\hline Sisil & 250 L Double door ice twister \\
\hline Sisil & 7 CB FT Single door \\
\hline Sisil & 8 Cb FT Double door \\
\hline Samsung & 180 L Direct Looling \\
\hline Samsung & 250 L Blue silver \\
\hline Samsung & 250 L Mist Silver \\
\hline Samsung & 585 L Side by side \\
\hline
\end{tabular}

Source: Annual report Singer Sri Lanka Ltd (2008)

According to Singer Sri Lanka Ltd annual report (2007) channels of refrigerator distribution, mega channel has recorded the highest percentage growth, while the traditional Singer channel reported highest revenue like in the past and spurred on by the successful "Mega Money" loyalty programme - that is also very much customer friendly loyalty programme introduced by Singer in business today. According to the annual repot (2006) the first brand evaluation carried by one of world's leading independent brand evaluation companies placed either as the most powerful consumer brand in Sri Lanka. Furthermore extended warranty scheme for durable goods such as refrigerator and washing machine which include extended two year warranty along with the one year Singer guarantee available for a very nominal fee payable at point of purchase and a three year warranty scheme that covers the product in case of repair. If a product requires repair, our authorized Singer technicians will provide you with free genuine parts plus expertise and reliable, trustful service. 